\title{
EVALUATION OF A CERAMIC ENTERPRISE REGARDING A SCOPE OF STRATEGIC MANAGEMENT AS A PART OF SUPPLY CHAIN
}

\section{DOI: 10.17261/Pressacademia.2021.1383 JMML- V.8-ISS.1-2021(1)-p.1-16}

\section{Ozden Ozkanlisoy ${ }^{1}$, Erkut Akkartal ${ }^{2}$}

${ }^{1}$ Istanbul Aydin University, Department of Aviation Management, Florya, Istanbul, Turkey. ozdenozkanlisoy@aydin.edu.tr, ORCID: 0000-0001-7879-0733

${ }^{2}$ Yeditepe University, Department of Logistics Management, Atasehir, Istanbul, Turkey. erkut.akkartal@yeditepe.edu.tr, ORCID: 0000-0002-7090-4449

\begin{tabular}{l}
\hline Date Received: December 10, $2020 \quad$ Date Accepted: March 2, $2021 \quad$ open OAaccess \\
\hline To cite this document \\
Ozkanlisoy, O., Akkartal, E. (2021). Evaluation of a ceramic enterprise regarding a scope of strategic management as a part of supply chain. \\
Journal of Management, Marketing and Logistics (JMML), V.8(1), p.1-16. \\
Permanent link to this document: $\frac{\text { http://doi.org/10.17261/Pressacademia.2021.1383 }}{\text { Copyright: Published by PressAcademia and limited licensed re-use rights only. }}$ \\
\hline
\end{tabular}

\section{ABSTRACT}

Purpose- The purpose of this study is to analyze the only $100 \%$ Turkish capital company, which has a significant place in the world in terms of its ceramic production capacity, in terms of strategic management, to guide other companies in the sector and thus increase the share of the ceramics industry in the Turkish economy by further increasing its share in exports.

Methodology- Strategic situation analysis was carried out in the study. In this context, the definition of the business, the situation analysis, the market definition, business external environment analysis, business environment analysis, business internal environment analysis, SWOT analysis and financial situation analysis were carried out. The new strategies were examined.

Findings- The shipping group company established by the firm has strengthened its brand perception in both domestic and export sectors with a new product introduced to the market and the product it created in the sector. At the same time, it has reached a low opportunity cost with the Italian brand. It is possible to say that the leading company of the sector, which has significant investments abroad, is on the right track with the investments made by the company, new products and new strategies. As a matter of fact, it is possible to see this with the increase in gross profit and operating profit in the annual report.

Conclusion- Supply chain design, planning, and operations decisions play an important role in a firm's success or failure. To remain competitive, supply chains need to be well-managed supply chains that adapt to changing technology and customer expectations. In addition to the companies in the ceramics industry, which has a significant share in exports, to make strategic situation analyzes, some changes must be made by the state.

Keywords: Ceramic enterprise, ceramic supply chain, strategic management, situation analysis JEL Codes: L61, L10, M10

\section{INTRODUCTION}

Ceramic industry is an industry branch that provides significant inputs to the construction sector, which consists of ceramic tile, ceramic sanitary ware, ceramic tableware and kitchenware, porcelain tableware and kitchenware, technical ceramics, refractory mortar and bricks, and ceramic raw materials (Agrafitois and Tsoutsos, 2001: 1231). Ceramic based on the history of the oldest civilization in Turkey as the first BC 6000 has been found. Due to the urbanization that took place in the 1960s, the Turkish ceramic industry has shown a rapid development with the effect of the construction industry (Turkey Ceramics Federation, 2010). It is still one of the most used materials today. Ceramic materials are frequently used in interior and exterior walls of buildings, wall coverings, bathrooms and kitchens, sanitary ware, electrical products, digital technologies and production tools (T.R. Presidency Strategy and Budget Office, 2020).

The sector which is one of Turkey's oldest and fastest moving sectors, improve their product every year and increase the diversity of its products. Sub-sectors of ceramics; ceramic tile, ceramic ware, refractory fire bricks, ceramic raw materials, ceramic kitchen and tableware, technical ceramic products (Turkey Ceramics Federation, 2010). Considering its installed 
capacity, product quality and diversity, and its share in total ceramic exports, the most developed sub-sectors in the Turkish ceramic industry are coating materials and sanitary ware. $57.2 \%$ of total ceramic exports consist of ceramic coating materials, $22.6 \%$ of ceramic sanitary ware, $11.7 \%$ of home and ornaments (Yasun, 2008).

In 2019, the foreign trade volume of the sector is $374169264 \mathrm{TL}$, and the merchandise trade deficit is 31239375 TL. The ratio of exports to imports is $84.6 \%$. This rate was $75.3 \%$ in 2018 and $67.1 \%$ in 2017 (TUIK, 2020). Therefore, it is possible to say that exports increased rapidly while imports decreased in the sector. Ceramic industry is also significant in terms of added value for our country to be one of the leading sectors. The fact that the ceramic industry is one of the sectors that uses domestic resources most in exports and has the least dependence on imported products is another factor that increases its importance for the Turkish economy (ISGAP, 2020).

Turkey's exports of ceramic tile show a significant change as markets. While exports have been mainly made to close and neighboring countries for many years, exports have been made mainly to developed Western countries markets for the last five years (TUIK, 2020). In Zion Market Research (2018), it was predicted that the global ceramics market will experience a growth of around 9.3\% in the period from 2018 to 2023 (Zion Market Research, 2018).

The management of an organization's long-term goal is called "strategic management"(Witcher, 2020: 2). Strategic management also examines why some firms are performing better than others (Dess et al., 2019: 6). A distinction is often made between strategic management and operations, but it should be borne in mind that the management of today's operations is the strategic management of tomorrow. Therefore, strategic management is also about managing an organization, including how operations serve the strategic needs of the organization's strategy (Witcher, 2020: 2).

The concept of supply chain management (SCM), in its broadest definition, refers to the ways companies produce, distribute and sell products and the coordination and cooperation efforts between all supply chain members while doing this (Khan and $\mathrm{Yu}, 2019:$ 23). Therefore, supply chain management affects operations that are also significant for strategic management.

Supply chain management supports businesses by optimizing core business practices, minimizing logistics expenses, and increasing customer satisfaction (Sun et al, 2015: 150; Al Zubayer et al., 2019: 793). In today's modern business world, competition occurs between companies' supply chains (Gunasekaran et al., 2004: 333). Supply chain design, planning, and operations decisions play an important role in a firm's success. To remain competitive, supply chains must be well-managed supply chains that adapt to changing technology and customer expectations (Chopra and Meindl, 2013: 6).

The element to be kept in mind here is that while supply chain management benefits all member companies, strategic management deals with the benefit of a single business. Companies that carry out the strategic management of each company well contribute to both the sector they are affiliated with and their own supply chain. In this context, the situation analysis, which is one of the components of the strategic management of the leading company in the sector, will be presented as an example to other companies and will serve as a guide for companies in both the Turkish ceramic industry and the global ceramic industry in this study. In addition, it guides other ceramic producers and suppliers about how the chain members will follow to increase the performance of the ceramic supply chain.

\section{CHARACTERISATION OF SUPPLY CHAIN IN CERAMIC INDUSTRY}

The supply chain is a network of organizations from upper players to lower players involved in different processes and activities to create value with products and services for end users (Christopher, 2005: 3-4). Supply chain management (SCM) consists of a series of approaches used to efficiently integrate suppliers, manufacturers, warehouses, and stores, and meets the service level requirement by ensuring that the goods are produced in the right quantities, in the right place and distributed to the right places at the lowest cost (Eko and Djokopran, 2002: 153).

Supply and Procurement- Working with multiple suppliers for the same commodity is one of the challenges of the ceramic supply chain. Long-term supply contracts are rare. The general trend in the ceramic supply chain is to keep more than one supply channel active at the same time. (Dondi et al., 2020: 6).

Manufacturing- The ceramic industry is generally an export-oriented sector. The European Union exports $30 \%$ of its total production. It covers around 2000 companies and has an annual production value of 30 billion Euros. Because it is an energyintensive industry, its competitiveness largely depends on fuel prices. Therefore, cost-effective strategies that increase energy efficiency and reduce carbon emissions affect ceramic production costs (Ceramie-Unie, 2019; Castro Oliveira, 2020: 6096). 
Wastes generated at every stage of production create environmental problems. The necessity of storing these wastes resulting from production also causes an additional cost (Poyraz and Yılmaz, 2018: 259).

Unlike classical production methods, 3D printing technique is also used in the processing of ceramic materials (Lipton et al., 2015: 114-115; Dankara et al., 2018: 231). The terms 3D printing and additive manufacturing have become interchangeable. The term layered production is defined as the technology or addition process of depositing successive thin layers of material on top of each other and producing a final three-dimensional product (Attaran, 2017: 196). In production technologies, along with 3D printing, it is expected that technological progress in nanotechnology will open new paths for ceramic industry participants. Nanotechnology has made an important contribution to the production of ceramic floor tiles. Nanotechnology provides resistance to bacteria and dirt and extends the strength and shelf life of tiles. It is estimated that a significant part of the demand for ceramic floor tiles produced with nanotechnology will come from food processing facilities, laboratories, and hospital (Global Ceramics Market Size Industry Analysis Report, 2019).

Transportion- Transportation activities in the ceramic supply chain are carried out over long and medium distances. For this reason, a multimodal transport network is used where more than one transport vehicle is used (Serpagli, 2020: 88-90). Due to the heavy weight of ceramic products and the limitation of tonnage in road vehicles, the transportation costs of the products are high. Companies providing logistics supply reflect this freight cost to their product prices. European countries reduce their transportation costs by using rail transportation (ESDH Ceramic Industry Macro Market Research, 2020a: 48-79).

Distribution- The distribution process should consider identifying the appropriate distribution channels regarding distance, travel time and supply and demand of each consumer (Bogataj et al., 2005: 93-94; Xiao et al., 2008; Perdana and Soemardjito, 2015). The long travel time during product distribution in the ceramic supply chain affects the quality of the goods and causes losses for traders. Delayed delivery process is also a factor that increases costs (Dondi et al., 2020: 6). In today's digitalizing world, information technologies are used extensively in the distribution of ceramic products (Ferreira et al., 2018: 292). According to a study, information technology-based supply chains significantly reduce delivery times and costs (Sethi, 2014).

Packaging- Ceramic products are classified as items to be broken (Worthy, 1982: 329-360). Special packaging and packaging materials are used while packing the fragile items.

Warehousing- The ceramic products are made of natural resources such as feldspar, quartz, ball clay, china clay and water (Choudhary and Sangwan, 2019: 1285). However, they require special storage as they are products that are susceptible to breakage and damage. Factories obtain their raw materials from their own enterprises or from external producers. Raw materials are generally stored in closed silos (Ministry of Environment and Urban, 2020: 6). Large amounts of wastes occur from the production of world ceramic coating companies. The storage or disposal of these wastes is a problem for companies (Ceramic Federation, 2017).

Logistics- Most of the ceramic enterprises are far from modern logistics. Ceramic logistics costs are higher than other industries. Ceramic business logistics generally includes the connections shown in Figure 1 below (Zou and Liu, 2019: 475):

Figure 1: Logistics Link of Ceramic Enterprise

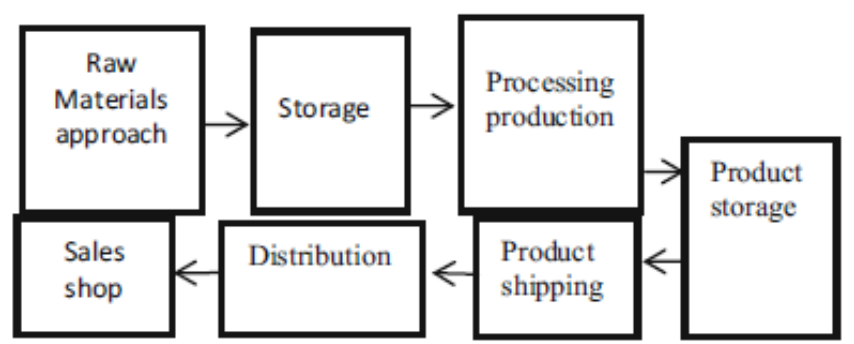

Source: Zou A., Liu J. (2019) Design of Integrated Logistics Model for Ceramic Enterprises in Liling. In: Huang G., Chien CF., Dou R. (eds) Proceeding of the 24th International Conference on Industrial Engineering and Engineering Management 2018. Springer, Singapore. https://doi.org/10.1007/978-981-13-3402-3_50 


\section{DATA AND METHODOLOGY}

The contribution of the ceramics industry to the Turkish economy is very significant as one of the sectors that uses domestic resources most in exports and has the least dependence on imported products. The aim of this study is to analyze the only $100 \%$ Turkish capital company, which has a significant place in the world in terms of its ceramic production capacity, in terms of strategic management, to guide other companies in the sector and thus increase the share of the ceramics industry in the Turkish economy by further increasing its share in exports.

The strategic management process, which is a significant management technique in determining the future goals and objectives of the organizations, enables the determination of the necessary activities for the companies to reach their goals (Bosemann and Phatak, 1989; Leskinen et al., 2006: 267). Secondary data were used within the scope of the study. The financial data within the scope of the study were obtained from the Public Disclosure Platform (KAP). Company's annual reports and general assembly presentations were used for situation analysis.

Situation analysis is a system recommended in basic case studies on strategic management issues from the beginning of the 21st century until today (Anderson and Vince, 2002). Situation analysis is defined as a simple but powerful tool used in assessing the strategic situation of a firm (Hussely, 2002: 43). While analyzing the strategic situation of the company within the scope of the study, firstly the definition of the business was made within the scope of the strategic situation analysis. Within the scope of the situation analysis, the market in which the company is located was defined first. Subsequently, business external environment analysis, business environment analysis, business internal environment analysis, SWOT analysis, financial situation analysis was performed and the company's new strategies were examined. Tabulation and graphics were used as descriptive statistics. Domestic data was used. Within the scope of the study, inferential results were obtained from tables and graphics. The study ends with the evaluation of the findings.

\section{FINDINGS AND DISCUSSIONS}

The foundations of the company included in the study were laid in 1957. Half the business processes of more than a century, has pioneered the establishment of the ceramics industry in Turkey and the world is a giant with investments in this area. The company has a production capacity of 68 million $\mathrm{m} 2$ per year and is the largest ceramics establishment producing in a single area (KAP, 2020c). The ceramic company within the scope of the study is one of the brands belonging to the same brand group. Group company has 17 companies today, each of which is a leader in their field. There are 6 brands owned by the company group. The group company grows every year by investing in developing and new sectors.

The ceramics industry is one of Turkey's oldest and fastest-moving sectors. The sector is a sector that develops its products every year and expands the variety of its products (Ceramic World Review, 2013). The contribution of the ceramic industry to the Turkish economy is very significant as one of the sectors that uses domestic resources the most in exports and has the least dependence on imported products. In addition, the Turkish ceramics industry is the most important industry with competitive experience abroad. The highest export and production rate of this sector, which has the highest rate of domestic raw material usage and very little import dependency, is in the ceramic tile product group (Kafalı, 2005). The export figures according to ceramic product types in the last five years in the Turkish ceramic industry are given in Table 1 below (TUiK, 2020; CCST,2020):

Table 1: Overall Turkey Ceramic Industry Exports (Million \$)

\begin{tabular}{|c|c|c|c|c|c|}
\hline YEARS & 2015 & 2016 & 2017 & 2018 & 2019 \\
\hline Ceramic tiles & 501 & 512 & 552 & 599 & 665 \\
\hline Ceramic sanitary ware & 198 & 212 & 231 & 259 & 272 \\
\hline Porcelain tableware and kitchenware & 68 & 68 & 80 & 81 & 84 \\
\hline Ceramic tableware and kitchenware & 31 & 24 & 22 & 27 & 30 \\
\hline Refractories & 121 & 116 & 132 & 172 & 156 \\
\hline Ceramic ornaments & 5 & 4 & 6 & 5 & 6 \\
\hline Bricks and tiles & 6 & 6 & 7 & 8 & 8 \\
\hline Other ceramic products & 3 & 4 & 5 & 7 & 5 \\
\hline TOTAL & 934 & 946 & 1036 & 1159 & 1225 \\
\hline
\end{tabular}

Reproduced from Source: TUIK, 2020 and CCST, 2020. https://data.tuik.gov.tr/ http://www.ccst.org.tr/arastirma/69e1d339-44a5-40a9-b1dae66c7f335668.pdf 
Ceramic exports are increasing over the years, while imports are gradually decreasing. While ceramic exports in the world were approximately 500 million dollars in 2015, it was 664 million dollars in 2019. Ceramic imports in the world were 78 million dollars in 2015 and 11 million dollars in 2019 (Turkish Ceramic Federation, 2020). The realization of the world ceramic foreign trade is given in Table 2 below (TUiK, 2020):

Table 2: Turkey's Foreign Trade by Ceramic

\begin{tabular}{ccccccc}
\hline YEARS & Export $\mathbf{( k g )}$ & Export $\left.\mathbf{( m}^{\mathbf{2}}\right)$ & Import $\mathbf{( k g )}$ & Import $\left.\mathbf{( m}^{\mathbf{2}}\right)$ & Export $\mathbf{( \$ )}$ & Import $(\mathbf{\$})$ \\
\hline 2015 & 1.324 .366 .286 & 77.169 .749 & 78.591 .133 & 3.810 .411 & 500.489 .206 & 78.203 .839 \\
\hline 2016 & 1.416 .870 .784 & 80.904 .446 & 60.796 .356 & 3.016 .712 & 512.539 .019 & 65.100 .119 \\
\hline 2017 & 1.603 .975 .120 & 89.869 .873 & 25.170 .465 & 1.255 .739 & 551.645 .578 & 32.683 .159 \\
\hline 2018 & 1.780 .550 .071 & 95.783 .335 & 16.910 .114 & 825.633 & 597.756 .864 & 18.089 .526 \\
\hline 2019 & 2.091 .541 .936 & 111.834 .129 & 10.437 .569 & 498.326 & 664.875 .075 & 11.378 .912 \\
\hline
\end{tabular}

Reproduced from Source: TUIK, (2020). Turkish Statistical Institute. Access adress https://data.tuik.gov.tr/

The industry's leading product group is ceramic tile (CCST, 2020). The Turkish ceramic tile industry has managed to have a say in the world of ceramic tile production, especially with the investments it has made after 1990. Turkish companies deliver their products to 60 countries today, and the competitive power of the Turkish ceramics industry in the world markets is increasing thanks to its growing production capacity, modern technology investments and high-quality advantages (Ceramic World Review, 2013).

In 2014, while some ceramic companies made new investments in the Turkish ceramic industry, some ceramic companies became stronger by purchasing ceramic companies from abroad. Turkish ceramic brands have purchased and incorporated 7 European giant ceramic brands in the last 7 years. In the ceramic market, Eczacıbaşı first purchased the ceramic tile division of German companies Engers Ceramic and German Villeroy \& Boch. Italian Fincuoghi, which has the Edilcuoghi, Edilgres and Campani brands, has been included in the scope of our company. Seramiksan and Ece Holding made the last purchase afterwards (Ministry of Science, Industry and Technology, 2015: 19).

Production, consumption and trade in the world ceramic industry is primarily affected by the developments in the world economy and trade and the world construction industry. A significant slowdown occurred in the world economy and trade and the construction sector in 2019. Accordingly, it is estimated that the production and consumption of ceramic tile will decline in 2019. In 2020, with the expectation of a relative recovery in the world economy and the construction industry, it is estimated that the production and consumption of ceramic tile will increase to a limited extent. In this framework, it is predicted that the production of ceramic coating materials, which decreased by 1.0 percent in 2019 , will increase by 2.0 percent in 2020 . While China will remain stable in the production increase, the contribution of India, Vietnam and Brazil will be seen. In addition, new producer countries such as Egypt and Thailand will also contribute. Production increases in Europe will be more limited. Depending on these developments, ceramic coating production, which was 13.00 billion square meters in 2019, is estimated to increase by 2.0 percent in 2020 to reach 13.25 billion square meters (CCST, 2020).

\subsection{Business External Environment Analysis}

External environment analysis consists of studies aimed at understanding the changes and developments in the external environment of the company and predicting the effects, opportunities, and threats that these changes and developments will create on the institution (Ginter et al., 1991: 35). With this analysis, the place allows making predictions for the future and responding to changes (Swayne et al., 2006: 48).

The external environment, the economic, legal, technological, economic component specifies how resources are distributed and used in the economy, and includes labor wages, inflation, taxes paid by workers and employers, prices of services and goods; The social component includes the characteristics, demographic and social values of the society in which the business is located; the political and legal component, the components associated with government affairs and the rules or laws that members of the community must comply with; technology includes innovations brought to the production of components, goods and services, research and development activities (Chou et al., 2012: 178-181). The general environment matrix, which includes the company's external environmental analysis for the market, is given in Table 3 below. 
Table 3: General Environment Matrix

\begin{tabular}{|c|c|c|c|c|c|c|c|}
\hline Environment & $\begin{array}{l}\text { Possible } \\
\text { Changes }\end{array}$ & $\begin{array}{l}\text { Possible } \\
O(+) / T(-) \\
\text { for Business }\end{array}$ & Impact & Probability & $\begin{array}{l}\text { Importance } \\
\text { Level }\end{array}$ & $\begin{array}{c}\text { Prep } \\
\text { Degree }\end{array}$ & $\begin{array}{l}\text { Resource } \\
\text { Adequacy }\end{array}$ \\
\hline Political & Change of government & + & 3 & 1 & 3 & 2 & 4 \\
\hline Legal & $\begin{array}{l}\text { Urban Transformation } \\
\text { Support }\end{array}$ & + & 6 & 6 & 36 & 6 & 6 \\
\hline Technological & $\begin{array}{l}\text { New Substitute } \\
\text { Products }\end{array}$ & + & 3 & 5 & 15 & 5 & 3 \\
\hline Sociocultural & Change in Pleasures & + & 2 & 3 & 6 & 4 & 4 \\
\hline Economic & Worsening Economy & + & 5 & 5 & 25 & 3 & 3 \\
\hline Demographic & $\begin{array}{l}\text { Increase in Target } \\
\text { Audience }\end{array}$ & + & 5 & 4 & 20 & 6 & 6 \\
\hline International & $\begin{array}{l}\text { Possible Extra Tax on } \\
\text { Turkish Products }\end{array}$ & - & 5 & 4 & 20 & 3 & 3 \\
\hline
\end{tabular}

When the external environment of the enterprise is examined in terms of the legal environment, the support of the state to urban transformation is a very significant legal arrangement for the opening of economic recession. Residents of some neighborhoods, especially in Istanbul, have created a strong investment in construction sector, especially on the Anatolian side. This created very new opportunities for the ceramic tile industry (Ceramics Working Group Report, 2015: 105-106). When technological environment is examined, especially large R\&D investments that trigger strong design and technological developments in Italy develop some substitute products. Ceramic applications that are heated and become liquid, then poured and cooled and cover the floor are in the test phase. This may be a development that changes the balances of the sector (T.R. Presidency Strategy and Budget Office, 2020: 5). In this study, 3D printing, also known as additive manufacturing, mentioned in the title number 2 , is a technology that makes significant contributions to the ceramic industry. Production with 3D printing is expected to be a dominant technology in the sector in the coming years (Global Ceramics Market Size, Industry Analysis Report, 2019).

When sociocultural environment is examined, social and cultural transformation process taking place in Turkey (Brennan and Herzog, 2014: 139). A social transformation in which conservative people and their lives are more dominant, widespread, and not afraid of being presented as before, but easily poured there like an identity, causes changes in the culture of pleasure and appreciation. It is very evident that the production and demand for products that are more like Arab and Islamic cultures has increased and this situation has revealed the necessity of reform especially in the design and production processes. In terms of economic environment, Turkey's economic development so far has been in line with the construction industry. The current construction industry is in stagnation. Currently, the development of the two sectors is evaluated together (ESDH Ceramic Industry Macro Market Research, 2020b). This affects the ceramic industry. For the production centers, which have a very large capacity and must fill their lines all the time like this company, the loss of even a year means that the costs increase both in production and stock and become unable to compete with the world. In terms of demographic environment, in particular, government efforts to promote marriage and childbearing may create medium and long-term opportunities for the construction industry. This will mean an increase in the target audience. Marriage and more children policy will mean more opportunities for the construction industry.

\subsection{Business Environment Competition Analysis}

Competition is defined as the battle between businesses to gain customers' appreciation, and it is also believed that competition is the secret hand that can best regulate the economy (Smith, 1776: 431). Recent developments in world trade have made it necessary to change the usual perspectives and approaches up to now.

Measuring the competitive situation in the field of business by measuring the powers of the five factors that affect competition in the sector of M. Porter is one of the important stages in the sectoral / business environment analysis. The competitive 
strategy model, which Porter developed in 1980 to explain the position of an industry in a complex strategic environment, consists of five force models. The five strengths offered in this model are supplier power, buyer power, entry barriers, triple substitution, and competitiveness (Porter, 1997: 12-17; Yunna and Yisheng, 2014: 799). Within the scope of the study, the subcriteria for each power were considered, the means of the criteria were calculated, and the following results were obtained for five powers:

Table 4: Results of Competition Analysis

\begin{tabular}{ll}
\hline Criteria & Mean Value \\
\hline Threat of New Firms & 3,69 \\
\hline Analysis of Suppliers / Bargaining Power of Suppliers & 2,78 \\
\hline Analysis of Customers / Bargaining Power of Customers & 2,1 \\
\hline The Threat of Alternative Goods & 2,9 \\
\hline Intensity of Competition Among Competitors & 2,66 \\
\hline
\end{tabular}

The first step of the competition analysis is competition between competitors. The sector, which has been under the rule of the first five big manufacturers for many years, has been opened to competition with the entry of medium-sized companies in recent years. However, the influence of large-scale companies continues in the market. This reinforces the view of a classical manufacturing sector far from the fragmented structure. Turkey dragging the sector, particularly companies, is an important opportunity in terms of structure. The company group is the second largest ceramic tiles company in the world with a production capacity of 67,9 million $\mathrm{m} 2$ / year (KAP, 2020c). The leader of the world market is the Italian Marazzi Group (Ceramic World Review, 2015). The company, which has constantly renewed its investments since its establishment, attaches importance to making international investments and opening to the world. The company, which recently bought Edilcoghi Edilgress brands from Italy, has become a signifcant player in Italy (Edilcuoghi Edilgres, 2020).

According to competition among competitors, the sector, which has been under the rule of the first five big manufacturers for many years, has been opened to competition with the entry of medium-sized companies in recent years. However, the influence of large-scale companies continues in the market. This reinforces the view of a classical manufacturing sector far from the fragmented structure.

Turkey dragging the sector, particularly companies, is an important opportunity in terms of structure. The company group is the second largest ceramic tiles company in the world with a production capacity of 67,9 million m2 / year (KAP, 2020c). The leader of the world market is the Italian Marazzi Group (Ceramic World Review, 2015). The company, which has constantly renewed its investments since its establishment, attaches importance to making international investments and opening to the world. The company, which recently bought Edilcoghi Edilgress brands from Italy, has become a significant player in Italy (Edilcuoghi Edilgres, 2020).

The company's main competitor in the Turkish ceramics industry is Vitra within the Eczacıbaşı Company. Making significant investments in the technology sector Eczacibasi Ceramic (Journal of Turkish Ceramics Federation, 2012: 35) are recognized in sector and are considered among the strongest groups in Turkey. When it was established, an agreement was made with the Italian company Marazzi and it was connected to production with the most advanced designs and techniques in ceramics. Having parted ways with Marazzi over time, the company formed a partnership with an Irish company in the summer of 1998 to establish Ireland's first ceramic tile factory. In addition, it is planned to export the tiles to be produced in this factory to Europe and America (Sabah Newspaper, 1998).

Other important competitors in the market are Ege and Toprak group. They are commercially strong and respected companies that value design and aesthetics. These companies are large-scale companies. The value that these companies attach to training managers and institutionalization continues to contribute to the total manager quality of the sector. medium-sized firms in the sector are contributing to the increase in Turkey's image and quality. In a meeting held in June 1999, ACIMAC, the Italian ceramic machine manufacturers association, ranked Seranit Seramik among the top 10 companies producing porcelain tiles all over the world (ACIMAC, 2020). All large and small companies in the sector have an international trade vision. The company included in the study has adopted a cost-oriented approach and focused on making a difference with some of its products in line with the Turkish ceramic perception in the world. First of all, the transportation group company established by the company was strengthened and logistics costs, one of the main items of the sector, were reduced. Thus, low costs per unit product were obtained and the firm became a firm with high welfare power. 
On the other hand, the company introduced a new product to the market. This product is still offered as the only manufacturer in Turkey. With this product, a higher price and brand perception has been created compared to the leading products in the market. In this way, the company has strengthened its brand perception in both domestic and export sectors. At the same time firm, putting the Italian brand their product range by producing some of the well has reached a certain audience cannot reach and compete in Turkey earlier this brand has achieved at lower cost opportunities.

When market entry barriers are examined, there is a moderate market entry barrier in the sector due to the capital need (Dinçer, 1996). Porcelain tile technology is a relatively new technology and is more expensive. This means a high capital requirement. An important issue that should be counted among the barriers to entry is the strong brand image of the industry leaders. A new company to enter the industry must invest significantly in its brand, otherwise it will be doomed to remain as a small producer and work with small price margins. Brand investment is also important to establish the distribution network across Turkey. The fact that the fixed investment in ceramic tile facilities does not allow the transformation into another production activity and is not cheap can be considered as an exit barrier. The allegations that sales are made below the cost encountered in the sector confirm this situation. In summary, there is a moderate entry barrier in the industry and exit will be a more difficult decision.

When it is looked into bargaining power of suppliers and customers, the buyers can choose strong brands in the absence of exorbitant price differences while choosing between brands. For this reason, the bargaining power of the buyers and the bargaining power of the seller can be evaluated from the same perspectives. The power of brands plays a very key role in buyers' preferences. As a natural consequence of this, brand segmentation is the most important engine of the sector. The price difference between strong brands is the only trump card that buyers have as a bargaining power.

In terms of threats of substitute products, ceramic tile was born as a substitute product. It has begun to replace natural stones such as marble and granite. Supply habits established on direct processing of previously existing mines have been broken with the development of ceramic production. The main reason for this is that ceramic is both a healthy and a lower cost product. However, ceramics have been losing power in the luxury consumption market in recent years, especially with the introduction of new and more hygienic natural stones. Particularly, some natural stones, which can absorb water and collect even oxide in the air, are more expensive, but have started to be preferred by those who can finance this. It is not perceived as a major threat because it coincides with a very small part of the market.

The first step of the competition analysis is examined threats of substitute products that may be alternative to business products. In this sense, we can say that companies in the market with strong brands are stronger than other sectors. In this sense, the company is the most advantageous company in the sector in terms of brand awareness and brand power because it is the first company in the sector. One of the company's brand name can be used as a generic brand name product in the near geography in Turkey.

\subsection{Business Internal Environmental Analysis}

The internal environment comprises of those conditions internal to the organization, including the organization's strategic resources, abilities, and management capabilities (Witcher, 2020: 29). One of the methods used in business internal environmental analysis is value chain analysis.

It is very useful to divide businesses into segments defined as value chains, each of which creates value, to better understand value-creating activities and thus to develop competitive advantage. It creates a certain value for each park in the value chain and thus contributes to the total profit. Value chain analysis also measures the value of each part in the chain and identifies its total contributions (Macmillan and Tampoe, 2000: 118). Value chain analysis enables businesses to review the inside of the organization to ensure cost effectiveness in resource utilization (Walters and Jones, 2001: 333). Value chain analysis is based on the search for strategies that will provide superior value to customers. With this analysis, the importance of the center of competitive relativity in achieving success in the sector where managers and strategists are located has been revealed.

Accordingly, competitive advantage arises from many separate activities that a firm carries out in designing, producing, marketing, delivering, and supporting its product (Porter, 1985: 37; Jacobs, 2003: 60-62). Each of the activities in the value chain can contribute to the relative cost position of a firm and can also provide a basis for differentiation. To evaluate this, the value chain strategically allocates a firm to its relevant activities. A firm gains competitive advantage by performing these strategically important activities cheaper or better than their competitors (Christopher, 2005: 13). The activities included in the value chain 
analysis developed by Michael Porter (1985) are grouped under two main headings as basic activities and support activities (Porter, 1985: 37). The activities of the company included in the study are evaluated in Figure 2 below:

\section{Figure 2: Value Chain Analysis}

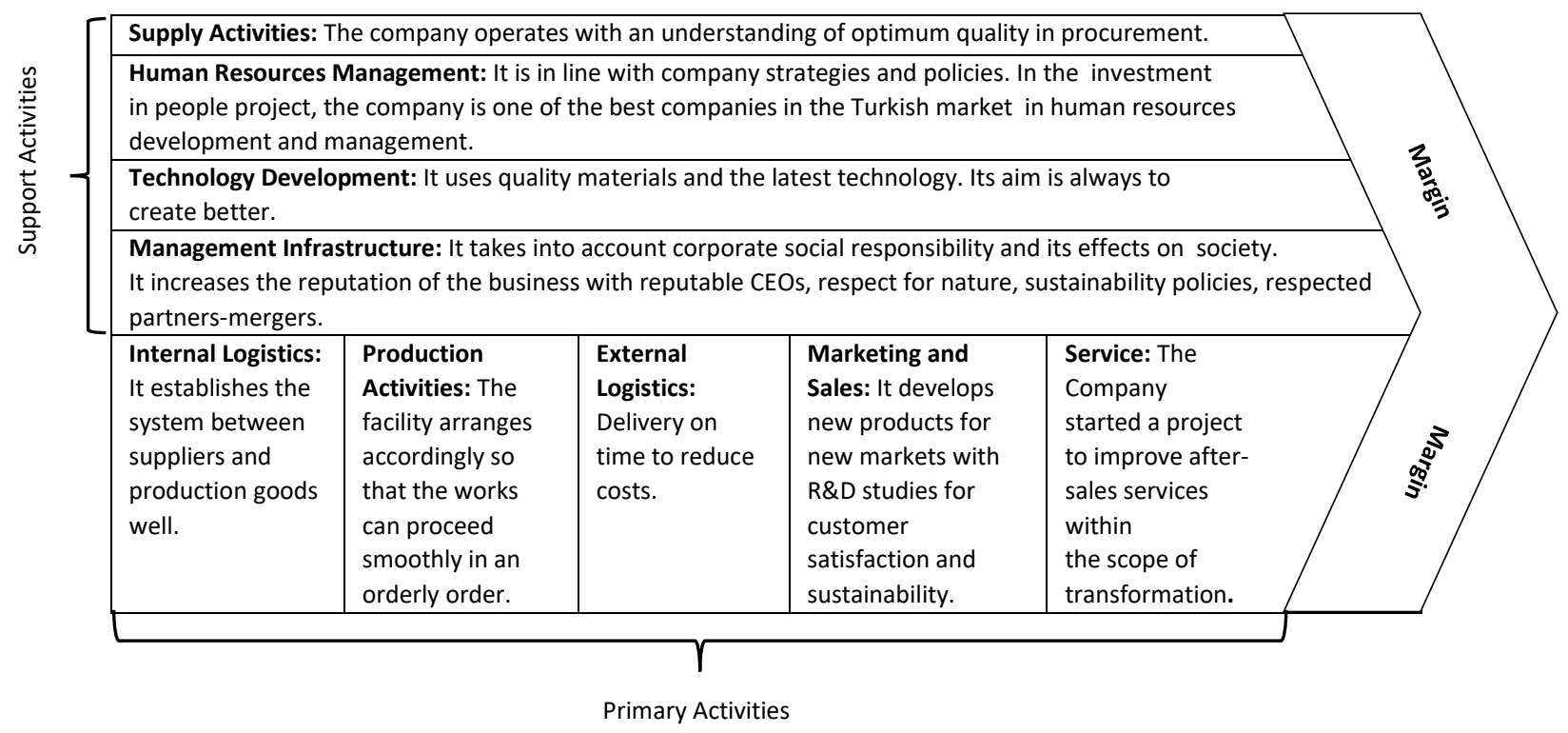

\subsection{SWOT Analysis}

Although the origin of the term "SWOT" is unknown, SWOT (strengths, weaknesses, opportunities, threats) analysis is performed to be a key tool to address complex strategic situations by reducing the amount of information to improve decision making in enterprises (Learned et al., 1969, Helms and Nixon, 2010: 216).

The most significant strengths of the company are the first ceramic exporter company in Turkey and is highly experienced in this field. The weaknesses of the firm are taken into consideration, the most significant weakness is that it is far from some raw materials. Looking at the opportunities and threats in the ceramic industry, there are many opportunities in the industry. There are also some opportunities and threats created by the pandemic period for the company. Different categories in Turkey of the Deloitte firm Covid-19 outbreaks according to the report entitled, in the building materials that were in the ceramics industry sector, sector of consumers with the renovations they have made at home is decomposed as positive from other sectors (Deloitte, 2020: 5). There is an increase in demand in this area. Despite the positive effect experienced compared to all these other sectors, exports in the ceramic sector decreased by $40 \%$ during the pandemic period (TIMDER, 2020). It is possible to say that this is related to the worsening economy all over the world. As a positive effect of the pandemic, the demand has shifted to Europe and Turkey in ceramics (Ekonomist, 2020). The company's SWOT Analysis is given below in Figure 3. 
Figure 3: SWOT Analysis

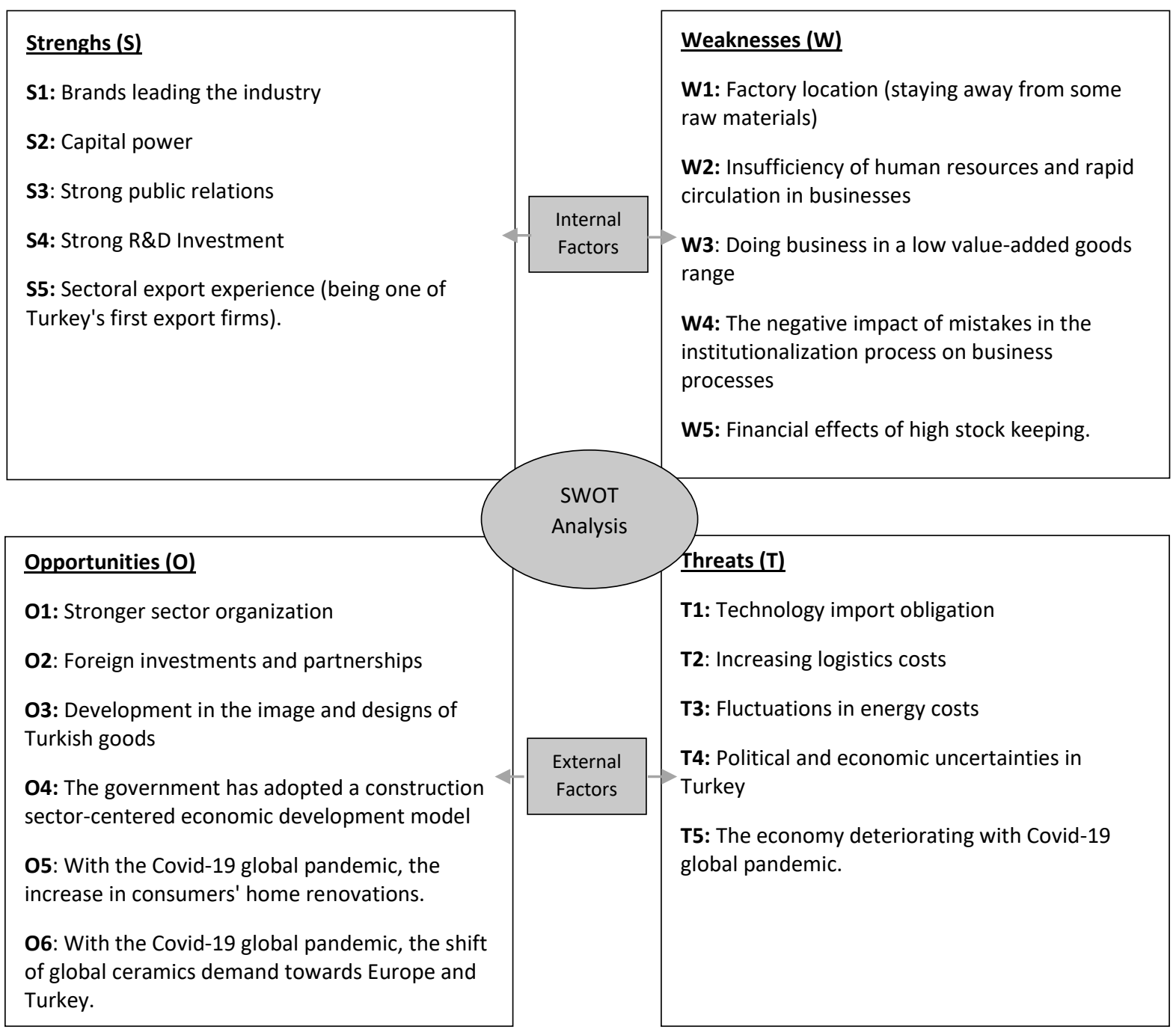

The company's strengths are that it is a leading company in the field of ceramics, strength of capital, public relations, and export experience. The company's lack of raw materials, insufficiency of human resources, low value-added product range constitute the weaknesses of the company. The ceramic industry is a highly organized sector and foreign investments, and partnerships are high. The development of the image of the Turkish ceramic industry is also a positive situation for the company. Covid-19 pandemic has led to an increase in home renovations and consumers began to shift global demand for ceramics to Europe and Turkey. However, there are also some threats created by the ceramic industry for the company. Increasing logistics costs, fluctuations in energy costs, the economy worsening with the Covid-19 pandemic are the most important threats. While the company takes advantage of the opportunities in the sector, it must also take precautions against threats.

\subsection{Financial Situation Analysis}

Since the balance sheets of the company were not published, only the company's publicly available annual reports could be used in financial situation analysis. Data) obtained from the activity reports published on the Public Disclosure Platform (KAP) were used to see the change in the last three operating years (KAP, 2020a; KAP, 2020b; KAP2020c). 
According to the company activity report for 2018; the total assets in the consolidated balance sheet for 2018 was 1363262 097 TL, and it increased by $14.54 \%$ compared to 2017. It occurred in current assets with an increase of $20.07 \%$ in 2018 compared to 2017. In the same year, fixed assets increased by $6.77 \%$ compared to the previous year. While short term debts decreased by $17.7 \%$, long term debts increased by $75.06 \%$. As of 31.12 .2018 , the firm had a net loss for the period. The company's equity decreased by $24.6 \%$ in the current period because of net period loss. Sales revenues increased by $16.93 \%$ compared to the previous year. Cost of sales, on the other hand, increased by $20.65 \%$ depending on foreign currency during the year and as a result, gross profit increased by $7.24 \%$. Consolidated operating profit increased by $23.33 \%$ compared to the previous period and reached 57767895 TL (KAP, 2020b).

According to the company activity report for 2019; in the consolidated balance sheet of 2019, the total assets amounted to 1 248348793 TL, with an increase of $8.43 \%$ compared to 2018 . Current assets decreased by $12.43 \%$ in 2019 compared to 2018 and amounted to $731258353 \mathrm{TL}$. In the same year, fixed assets decreased by $2.11 \%$ compared to the previous year and amounted to TL 517090 440. While short term debts decreased by 12\%, long term debts increased by 40.6\%. As of 31.12.2019, the company had a net loss for the period. The firm has shown a decrease in equity in the current period because of net period loss. Sales revenues decreased by $10.74 \%$ compared to the previous year. Cost of sales increased by $5.12 \%$ during the year due to foreign currency and as a result gross profit decreased by $57.17 \%$. Loss has been realized in consolidated main operations (KAP, 2020c). In 2019, global tile production and consumption experienced a decline. The production and consumption of ceramic tile worldwide decreased by $3.7 \%$ and $4 \%$, respectively, to $12.7 \mathrm{~m} 2$ and 12.4 billion $\mathrm{m} 2$ (Ceramic World Review, 2020). Considering this contraction in the ceramic industry, it is possible to say that the loss of the company in 2019 is related to the sectors. When the financial status of the firm in 2018 is analyzed, there is a positive situation with the increase in gross profit and net profit.

New Strategies and Strategic Focus Fields: The concept of strategy originates from the Greek word "stratego" and means "art of the general". In addition to formulating and developing strategies by senior management, they can be put into practice with the participation of managers at all levels (Mescon et al., 1997: 487). The specific execution of strategies and plans together is an important factor that leads businesses to success. Table 5 shows the effects of strategies and actions on the success of businesses below (Tregoe and Zimmerman, 1981: 15-19):

Table 5: The Effects of Strategy and Actions on Business Success

\begin{tabular}{lll}
\hline & Certain Plans & Uncertain Plans \\
\hline $\begin{array}{l}\text { Effective } \\
\text { Actions }\end{array}$ & $\begin{array}{l}\text { Certain strategies and effective actions will be } \\
\text { successful in the future as in the past. }\end{array}$ & $\begin{array}{l}\text { Uncertain strategy but effective action has been } \\
\text { successful in the past, but it is doubtful whether it will } \\
\text { bring success in the future. }\end{array}$ \\
\hline $\begin{array}{l}\text { Ineffective } \\
\text { Actions }\end{array}$ & $\begin{array}{l}\text { Although ineffective actions with a certain } \\
\text { strategy have brought success from time to time } \\
\text { in the past, competition is expected to strengthen } \\
\text { in the future. }\end{array}$ & $\begin{array}{l}\text { Uncertain strategy and ineffective actions will bring } \\
\text { failure in the future as in the past. }\end{array}$ \\
\hline
\end{tabular}

Reproduced from Source: Tregoe, B. B. and Zimmerman, J. W. (1981). The new strategic manager. Business, 31(3), 15-19.

Since certain strategies and effective actions are a strategic management element that succeeds in the future as in the past, the company included in the study has entered a transformation process in this direction and has determined new strategies in this transformation process.

When examining the company's new strategic focus areas and projects carried out for this purpose, the company has gathered its strategic focus areas under four dimensions. These consist of financial dimension, customer dimension, internal functioning dimension and learning and development dimensions. The company aims at sustainable profitable growth with its financial strategic focus. To achieve this goal, it aims to lead the domestic ceramic tile market, grow in the bathroom business area, grow abroad and effective resource management. It implemented the domestic channel development project to grow in the domestic ceramic tile and bathroom business area. It has carried out strategic overseas marketing plans to grow abroad and has achieved KS-KI integration. It realizes operational savings with effective resource management.

It aims to increase the end consumer loyalty and make its brands pioneering and innovative by raising the service level to achieve its target in the strategic customer focus. To increase the end consumer loyalty by raising the service level, it analyzes 
the end consumer customer experiences, conducts studies for the development of the digital strategy, process, vision and business requirements project and after-sales services. It manages the determination of product portfolio strategies and future lab studies for its brands to continue as a pioneer and innovative. The company's goal is operational excellence in the focus of strategic internal processes. In this direction, the company carried out supply chain management transformation program, lean transformation program, field and data automation and R\&D projects. In the focus of strategic learning and development, the company's objectives are to develop a market-oriented profitability management system, to work with qualified human resources, to establish employee and satisfaction loyalty, corporate culture, digitalization and information infrastructure. Practices carried out in this context are corporate culture and development plans and digital transformation. Some of the projects carried out by the firm mentioned above within the scope of its strategic focus are discussed below:

One of the company's new strategies is "the final consumer customer experience project". The company wants to create an experience that makes a difference. For this purpose, it determines the improvement fields. It does this by meeting with dealer employees and customers and by observing the store. Channels that will reach target customer segments are determined and the channel is matched according to customer expectations. Another strategy of company is "domestic channel development project". The company aims to increase the number of points in line with the retail vision by diversifying the points in its sales network with Select and Point of Sale. Increasing the number of stores from 5 to 10 within five years, increasing the number of Select stores from 11 to 50, increasing the number of dealers from 145 to 140-160, increasing the sales points to 350, and increasing the number of sub-dealers of 1100 to the range of $800-1200$ are aimed to be increased. Target values are approximate values.

"Digital strategy, process, vision and business requirements project" is another strategy. Strategies have been digitized to spread domestic end consumer customer experience studies to all customers and channel partners in Turkey and abroad. "After sales service improvement project" is also a new strategy. To increase customer satisfaction, it works with an authorized service consisting of expert teams in the business where customer suggestions and complaints are evaluated. It also ensures the perfect and safe assembly of its products. It works with fast, experienced, and reliable service understanding.

\section{CONCLUSION}

Ceramic sector grew more share in parallel with the construction industry, while being overseas in Turkey in terms of inputs and exports are an important position because it is a great contribution. For this reason, it would be appropriate to take a closer look at the sector, to choose the leading companies of the sector to increase the exports of all companies in the sector and to guide other companies by analyzing their strategic situation. According to researches, growth was expected in the global ceramic market for the next three years before the current major global pandemic Covid-19. If we assume that the sectors will start to recover after the pandemic and this growth will take place, companies should carry out situation analysis, which is the first step of strategic management, and determine their future strategies for companies to get their share from this growth and thus increase exports.

The company included in the study has adopted a cost-oriented approach and focused on making a difference with some of its products in line with the Turkish ceramic perception in the world. Firstly, the transportation group company established by the company was strengthened and logistics costs, one of the main items of the sector, were reduced. Thus, low costs per unit product were obtained and the firm became a firm with high welfare power.

On the other hand, the company introduced a new product to the market. These products are available as still the only manufacturer in Turkey. With this product, a higher price and brand perception has been created compared to the leading products in the market. Thus, the company has strengthened its brand perception in both domestic and export sectors. At the same time, the firm assortment of Italian brand has reached a certain audience cannot reach a portion of the previously producing wells and putting these brands to compete in Turkey has reached its lower opportunity cost.

Looking at the competition analysis, the intensity of competition between competitors in the sector is high. The bargaining power of suppliers and customers in the sector is low. The threat posed by alternative products is moderate. Looking at the SWOT analysis, the most significant strengths of the company, is the first ceramic exporter company in Turkey and is highly experienced in this field. The weaknesses of the firm are taken into consideration, the most significant weakness is that it is far from some raw materials. Looking at the opportunities and threats in the ceramic industry, there are many opportunities in the industry. 
When we examine the leading company of the sector, which has significant investments abroad, which is included in the scope of the study, it is possible to say that the company is on the right track with the investments it has made, the new products it has developed and the new strategies it has chosen, while ignoring the year 2019, when the pandemic period was significantly affected. As a matter of fact, the firm proves this with its gross profit in 2018 annual report and the increase in operating profit.

The firm has shown a decrease in equity in the current period because of net period loss in 2019. Sales revenues decreased by $10.74 \%$ compared to the previous year. Cost of sales increased by $5.12 \%$ during the year due to foreign currency and as a result gross profit decreased by $57.17 \%$. Loss has been realized in consolidated main operations (KAP, 2020c). In 2019, global tile production and consumption experienced a decline. The production and consumption of ceramic tile worldwide decreased by $3.7 \%$ and $4 \%$, respectively, to $12.7 \mathrm{~m} 2$ and 12.4 billion $\mathrm{m} 2$ (Ceramic World Review, 2020). Considering this contraction in the ceramic industry, it is possible to say that the loss of the company in 2019 is related to the sectors. It is possible to say that the primary and support activities in the value chain analysis make a positive contribution to the profit margin.

Supply chain design, planning, and operations decisions play a significant role in a firm's success or failure. To remain competitive, supply chains must be well-managed supply chains that adapt to changing technology and customer expectations (Chopra and Meindl, 2013: 6). It is anticipated that the company will increase its profit margin by increasing its operational efficiency with the projects it has put forward within the scope of new strategic focuses such as supply chain management and digital transformation. Reviewing support services and processes and integrating them into company operations will also increase productivity.

When it comes to other suggestions for the company, products and campaigns planned according to regional product needs can be organized to meet different customer needs in domestic and foreign markets. Efforts can be made to increase the sales of the company's ceramic coating products for different usage areas such as furniture and white goods. Efforts can be made to liquefy idle assets that do not generate income.

While suggestions are given for the company, it is necessary to emphasize the recommendations for the sector. Unfortunately, the Turkish ceramics industry bears high transportation costs due to the high use of road transportation in the export of ceramic products and in the transportation of raw materials and products in the domestic market. For this sector, which has an important share in exports, to move forward, some changes should be made by the government, as well as the strategic analysis of the companies. To reduce the transportation costs in the ceramic industry, it is necessary to develop rail transport to the designated areas for raw materials and production facilities in the domestic market. It is necessary to develop intermodal transportation solutions that will reduce transportation costs for foreign markets. Establishing specialized customs points specific to the sector is also a significant suggestion for the Turkish ceramic industry.

\section{REFERENCES}

ACIMAC, (2020). Associazione Costruttori Italiani Macchine Attrezzature per Ceramica. Retrieved from https://www.acimac.it/ac-en/

Agrafiotis, C. and Tsoutsos, T. (2001). Energy saving technologies in the European ceramic sector: a systematic review. Applied thermal engineering, 21(12), 1231-1249.

Al Zubayer, M. A., Ali, S. M. and Kabir, G. (2019). Analysis of supply chain risk in the ceramic industry using the TOPSIS method under a fuzzy environment. Journal of Modelling in Management. 14(3), 792-815.

Attaran, M. (2017). Additive manufacturing: the most promising technology to alter the supply chain and logistics. Journal of Service Science and Management, 10(03), 189.

Anderson, C. and Vince, J. (2002). Strategic Marketing Management, Boston: Houghton Mifflin Harcourt

Bogataj, M., Bogataj, L. and Vodopivec, R. (2005). Stability of perishable goods in cold logistic chains. International Journal Production Economics, Volumes 93-94, 345-356.

Bosemann, G. and Phatak, A. (1989). Strategic management: text and cases (2nd. Ed.). New York: John Willey Sons.

Brennan, S. and Herzog, M. (2014). Turkey and the politics of national identity: Social, economic and cultural transformation. London: Bloomsbury Publishing.

Castro Oliveira, M., Iten, M., L Cruz, P. and Monteiro, H. (2020). Review on Energy Efficiency Progresses, Technologies and Strategies in the Ceramic Sector Focusing on Waste Heat Recovery. Energies, 13(22), 6096. 
CCST, 2020. Cement, Glass, Ceramics and Soil Products Exporters' Association. Retrieved from http://www.ccst.org.tr/arastirma/cb9e840f-e1984ccc-ae18-7da6b007c96e.pdf

Ceramic Federation, (2017). Retrieved from http://www.serfed.com/mailing/mail files/75556 ZBO Eskisehir Sunumu 0107 2010 text.pdf

Ceramie-Unie, (2019). The European Ceramic Industry Association. Retrieved from http://cerameunie.eu

Ceramic World Review, (2015). Ceramic World Web. Retrieved from https://www.ceramicworldweb.it/cww-en/news/tiles/shopping-in-theitalian-ceramic-district-marazzi-acquires-emilceramica/

Ceramic World Review, (2020). Ceramic World Review Report 138/2020. Retrieved from https://www.ceramicworldweb.it/cwwen/magazines/ceramic-world-review-1382020/

Ceramic World Review, (2013). Tile Edizioni, Volume June / July.

Ceramics Working Group Report, (2015). T.R. Ministry of Development Tenth Development Plan 2014-2018 Ceramics Working Group Report, Ankara. ISBN 978-605-9041-54-6.

Christopher, M. (2005). Logistics and Supply Chain Management: Creating Value-Adding Networks (3th Ed.), New Jersey: FT Press.

Chopra, S. and Meindl, P. (2013). Supply Chain Management: Strategy, Planning, and Operation (5th Ed.). New Jersey: Pearson Education.

Chou, C. C., Yih, J. M., Wong, C. P., Chang, H. T., Chen, M. H., Chang, H. W. and Lin, C. Y. (2012). SWOT Analysis of Operation Strategies of the World's Top 20 Carriers. In Applied Mechanics and Materials (Vol. 178, pp. 2863-2866). Switzerland: Trans Tech Publications Ltd.

Choudhary, K. and Sangwan, K. S. (2019). Multiple case study analysis and development of an interpretive structural model for greening of supply chains in Indian ceramic enterprises. Management of Environmental Quality: An International Journal.

Dankara, I., Haddaraha, A., Omara, F.E.L., Sepulcreb, F. and Pujolàb, M. (2018). 3D printing technology - The new era for food customization and elaboration. Trends in Food Science \& Technology, 75, 231 - 242.

Deloitte, (2020). Effects of Different Categories of Global COVID-19 global pandemic in Turkey. Issue I. April, 2020. Retrieved from https://www2.deloitte.com/tr/tr/pages/consulting/articles/kuresel-covid-19-salgininin-turkiyede-farkli-kategorilere-etkileri.html

Dess, G., McNamara, G., Eisner, A. and Lee, S. (2019). Strategic Management: Text and Cases (9th Ed.) New York: McGraw-Hill. ISBN10: 1259813959 ISBN13: 9781259813955

Dinçer, Ö. (1996). Stratejik Yönetim ve İşletme Politikası Ders İçi Tartışmalar, M.Ü., İstanbul.

Dondi, M., García-Ten, J., Rambaldi, E., Zanelli, C. and Vicent-Cabedo, M. (2020). Resource efficiency versus market trends in the ceramic tile industry: Effect on the supply chain in Italy and Spain. Resources, Conservation and Recycling, 105271.

Edilcuoghi Edilgres, (2020). Edilcuoghi Edilgres Company. Retrieved from https://www.edilcuoghiedilgres.com/en/collezioni/

Eko, R. and Djokopran, R. (2002). Konsep manajemen supply chain. Indonesia: Grasindo Publisher

ESDH Ceramic Industry Macro Market Research, (2020a). Retrieved from https://www.serfed.com/upload/ihracatrakamlari/SERAM\%C4\%B0K\%20SEKT\%C3\%96R\%C3\%9C\%20MAKRO\%20PAZAR\%20ARA\%C5\%9ETIRMASI\%20RAPORU-2017-03.pdf

ESDH Ceramic Industry Macro Market Research, (2020b). Effects of Covid-19 Outbreak on Construction and Ceramics Industry and Expectations. Retrieved from http://www.ccst.org.tr/arastirma/61c6d9ae-8b26-466f-82e2-2ab974c71c8b.pdf

Ekonomist, (2020). Seramik sektöründe yeni fırsatlar. Retrieved from https://www.ekonomist.com.tr/kulis/seramik-sektorunde-yenifirsatlar.htm

Ferreira, L., Lopes, N., Silva, J., Putnik, G. D., Cruz-Cunha, M. M. and Ávila, P. S. (Eds.). (2018). Technological Developments in Industry 4.0 for Business Applications. USA: IGI Global.

Ginter, P.M., Duncan, W.J., Richardson, W.D. and Swayne, L.E. (1991). Analyzing The Health Care Environment: You Can't Hit What You Can't See. Health Care Manage Rev, 16(4), 35-48.

Global Ceramics Market Size Industry Analysis Report, (2019). Ceramics Market Size, Share \& Trends Analysis Report By Product (Traditional, Advanced), By Application (Sanitary Ware, Abrasives, Tiles), By End-Use; By Region, And Segment Forecasts, 2019 - 2025. Retrieved from https://www.grandviewresearch.com/industry-analysis/ceramics-market

Gunasekaran, A., Patel, C. and McGaughey, R.E. (2004), "A framework for supply chain performance measurement", International Journal of Production Economics, Vol. 87 No. 3, pp. 333-347.

ISGAP, 2020. The Institute for the Study of Global Antisemitism and Policy. Retrieved from http://www.isgap.gov.tr/seramik/ 
Jacobs, D. G., 'Anatomy of a Supply Chain', Transportation \& Distribution, June 2003, pp. 60-62.

Journal of Turkish Ceramics Federation, (2012). Journal of Turkish Ceramic Federation, Volume: 39, March-May 2012. Retrieved from https://serfed.com/upload/dergiler/Seramik\%20T\%C3\%BCrkiye\%20-\%20Sekt\%C3\%B6rel\%20(39).pdf

Kafalı, M.A. (2005, Mayıs). Seramik Yer ve Duvar Kaplamaları. Türkiye Kalkınma Bankası A.Ş. Sektörel Araştırmalar Müdürlüğü, Ankara, pp. 1-60.

Khan, S. A. R. and Yu, Z. (2019). Strategic Supply Chain Management, EAl/Springer Innovations in Communication and Computing, Berlin:

Springer. https://doi.org/10.1007/978-3-030-15058-7_2

KAP (2020a). Company Annual Activity Report for 2017 Retrieved from https://www.kap.org.tr/tr/Bildirim/667224

KAP (2020b). Company Annual Activity Report for 2018 Retrieved from https://www.kap.org.tr/tr/Bildirim/746802

KAP (2020c). Company Annual Activity Report for 2019 Retrieved from https://www.kap.org.tr/tr/Bildirim/826545

Leskinen, L.A., Leskinen, P., Kurttila, M., Kangas, J. and Kajanus, M., (2006), “Adapting modern strategic decision support tools in the parcipatory strategy process-a case study of a forest research station", Forest Policy and Economics, 8, 267-278.

Lipton, J.I., Cutler, M., Nigl, F., Cohen, D. and Lipson, H. (2015). Additive manufacturing for the food industry. Food Science \& Technology, 43, $114-123$

Macmillan, H. and Tampoe, M. (2000). Strategic Management. New York: Oxford University Press.

Mescon, M. H., Albert, M. and Khedouri, F. (1997). Osnovy menedzhmenta [Management]. Moscow: Delo Publication.

Ministry of Environment and Urban, (2020). Ceramic Production, Sectoral Application Guide, Facilitating the Application for Determining and Reducing Air Pollution Resulting from Industry Retrieved from https://webdosya.csb.gov.tr/db/sanayihavarehberi/icerikler//23 seram-k-uret-m-20200103075114.pdf

Ministry of Science, Industry and Technology, (2015). Ceramic Industry Report, 2015/1.

Perdana, Y. R. and Soemardjito, J. (2015). Model Jaringan Rantai Pasok Komoditi Perikanan Dalam Rangka Mendukung Sistem Logistik Ikan Nasional. Jurnal Transportasi Multimoda, 13(1), 31-40.

Porter, M. E. (1997). Competitive strategy. Measuring business excellence. 1 (2). pp. 12-17.

Porter, M. E. (1985). Competitive Advantage: Creating and Sustaining Superior Performance. New York: Free Press.

Poyraz, M. and Yılmaz, Z. (2018). Seramik Karo Sektöründe Sürdürebilirlik ve Geri Dönüşüm. Anadolu Üniversitesi Sanat ve Tasarım Dergisi, 8(1), 256-270.

Sabah Newspaper, (1998). “Eczacıbaşı İrlanda'da Karo Fabrikası Kuruyor”, Sabah Newspaper, 03 Temmuz 1998.

Serpagli, P. (2020). Intralogistics: innovative technologies and new management models. Ceramic World Rev. 135. 88-90.

Sethi, J. (2014) 3D Printing and Its Implications for the Global Logistics Industry. Retrieved from http://electronicsmaker.com/3d-printing-andits-implications-for-the-global-logistics-industry

Smith, A. (1776). 1776. The Wealth of Nations. Oxford: Oxford University Press.

Sun, C., Xiang, Y., Jiang, S. and Che, Q. (2015), "A supply chain risk evaluation method based on fuzzy TOPSIS", International Journal of Safety and Security Engineering, Vol. 5 No. 2, pp. 150-161.

Swayne, L.E., Duncan, W.J. and Ginter, P.M. (2006). Strategic Management of Health Care Organizations. UK: Blackwell Publishing.

TIMDER, (2020). Trade Association for Sanitary and Building Supplies. Retrieved from https://www.timder.org.tr/haber/SektordenHaberler/Salginin-Durduramadigi-Seramik-Sektorunde-Ihracat-40-Azaldi/1891

T.R. Presidency Strategy and Budget Office, 2020. Retrieved from https://sbb.gov.tr/wpcontent/uploads/2018/10/10_SeramikCalismaGurubu.pdf

Tregoe, B. B. and Zimmerman, J. W. (1981). The new strategic manager. Business, 31(3), 15-19.

TUIK, 2020. Turkish Statistical Institute. Retrieved from https://data.tuik.gov.tr/

Turkey Ceramics Federation, (2010). 1990-2009 Turkish Ceramic Industry, Istanbul.

Walters, D. and Jones, P. (2001). Value and Value Chains in Healthcare: A Quality Management Perspective. The TQM Management, 13 (5), 319333. 
Witcher, B. J. (2020). Absolute Essentials of Strategic Management. UK: Routledge.

Worthy, L. H. (1982). Classification and interpretation of late-nineteenth-and early-twentieth-century ceramics. In Archaeology of Urban America. Cambridge: Academic Press.

Xiao, Y., Chen, J. and Xu, X. (2008) Fresh Product Supply Chain Coordination under CIF Business Model with Long Distance Transportation. System Engineering Theory and Practice, Vol 8 Issue 2.

Yasun, B., (2008). Tozlardan kaynaklanan problemler koruma önleme yöntemleri. (Yayımlanmamış yüksek lisans tezi), Ankara.

Yunna, W. and Yisheng, Y. (2014). The competition situation analysis of shale gas industry in China: Applying Porter's five forces and scenario model. Renewable and Sustainable Energy Reviews, 40, 798-805.

Zion Market Research (2018). Retrieved from www.globenewswire.com/news-release/2019/07/16/1883068/0/en/Global-Ceramic-Balls-MarketWill-Reach-USD-809-Million-By-2026-Zion-Market-Research.html

Zou A. and Liu J. (2019) Design of Integrated Logistics Model for Ceramic Enterprises in Liling. In: Huang G., Chien CF., Dou R. (eds) Proceeding of the 24th International Conference on Industrial Engineering and Engineering Management 2018. Singapore: Springer

https://doi.org/10.1007/978-981-13-3402-3_50 